\section{Journal of Anatolian Environmental and Animal Sciences \\ (Anadolu Çevre ve Hayvancılık Bilimleri Dergisi) \\ Doi: https://doi.org/10.35229/jaes.530139}

\title{
Larvacidal Activity of Some Medicinal Plants Naturally Growing in Turkey Against Aedes albopictus (Diptera: Culicidae)
}

\author{
Emine KILIÇKAYA SELVi ${ }^{1^{*}}$ \\ Asu USTA ${ }^{1}$ \\ M. Mustafa AKINER ${ }^{2}$ \\ ${ }^{1}$ Department of Chemistry, Faculty of Arts and Sciences, Recep Tayyip Erdogan University, 53100 Rize, TURKEY. \\ ${ }^{2}$ Department of Biology, Faculty of Arts and Sciences, Recep Tayyip Erdogan University, 53100 Rize, TURKEY \\ * (D): https://orcid.org/0000-0003-0291-5362 1 (D): https://orcid.org/0000-0002-1826-9599 2 (D): https://orcid.org/0000-0002-7658-3236
}

How to cite: Kılıckaya Selvi, E., Usta, A. \& Akıner, M.M. (2019). Larvacidal activity of some medicinal plants naturally growing in Turkey against Aedes albopictus (Diptera: Culicidae). Anatolian Env. and Anim. Sciences, 4(1), 53-59. Doi: https://doi.org/10.35229/jaes.530139

Atıf yapmak için: Kılıçkaya Selvi, E., Usta, A. \& Akıner, M.M. (2019). Türkiye'de doğal olarak yetişen bazı tıbbi bitkilerin Aedes albopictus (Diptera: Culicidae)'a karşı larvasidal aktiviteleri. Anadolu Çev. ve Hay. Dergisi, 4(1), 53-59. Doi: https://doi.org/10.35229/jaes.530139

\begin{abstract}
Massive use of chemical based insecticides led to detrimental effects on the public health and environment. Environment friendly and biodegradable natural products of plant origin alternatives to synthetic larvacids have received attention as agents for vector control. Thus, many researchers have studied on alternative methods for pest control instead of chemical ones.

In this study, some medicinal valuable plants naturally growing in Turkey were selected for this purpose and the larvicidal effect against Asian tiger mosquito Aedes albopictus larvae was investigated. Bioassays were carried out by appliying late $3^{\text {th }}$ to early $4^{\text {th }}$ instar larvae of Aedes albopictus to two different dose of plant extracts. The larval mortality was counted after 24 and $48 \mathrm{~h}$ after experiments. Bioassay results revealed that Leucanthemum vulgare was the most effective for ethyl acetate extract in $500 \mathrm{ppm}$ concentration, $100 \%$ for $24 \mathrm{~h}, 100 \%$ for $48 \mathrm{~h}$. Salvia vertisillata induced a second high mortality after $24 \mathrm{~h}$ treatment for two doses of both extracts. Inula vulgaris and Matricaria chamomilla produced high and moderate mortality for $500 \mathrm{ppm}$ dose of both extracts, respectively.

Our results evidenced that the high larvicidal activity was detected products obtained from crude extracts with ethyl acateta and methyl alcohol of Salvia verticillata, Leucanthemum vulgare, Inula vulgaris and Matricaria chamomilla. But there is a need for further studies about possible candidate species for new and safer control products against mosquito control.
\end{abstract}

Keywords: Aedes albopictus, larvicidal activity, mosquito control, plant extracts.

\section{Türkiye'de Doğal Olarak Yetişen Bazı Tıbbi Bitkilerin Aedes albopictus (Diptera: Culicidae)’a Karşı Larvasidal Aktiviteleri}

Öz: Kimyasal insektisitlerin yoğun kullanımı halk sağlığı ve çevre üzerinde olumsuz etkilere sebep olmuştur. Bu durum, sentetik larvasitlere alternatif, bitki kökenli çevre dostu ve biyobozunur doğal ürünler vektör kontrolünde dikkat çekmiştir. Bu nedenle birçok araştırmacı, kimyasal olanlar yerine haşere kontrolü için alternatif yöntemler üzerinde çalışmıştır.

Bu çalışmada, Türkiye'de doğal olarak yetişen bazı tıbbi bitkiler, bu amaç için seçilmiş ve Asya kaplanı sivrisinek Aedes albopictus larvalarına karşı larvasit etkileri araştırılmıştır. Biyoassayler, Aedes albopictus'un geç 3. ile erken 4. evre larvalarının iki farklı bitki ekstraktına uygulayarak gerçekleştirilmiştir. Larva ölümleri, deneylerden 24 ve 48 saat sonra sayılmıştır. Biyoassay sonuçları, Leucanthemum vulgare'nin etil asetat özütünün 500 ppm'lik konsantrasyonda 24 saatte \% 100, 48 saatte \% 100 oranında en etkili olduğunu gösterdi. Salvia vertisillata, her iki ekstraktın iki dozu için 24 saat uygulamadan sonra ikinci yüksek ölüm oranı yaratmıştır. Inula vulgaris ve Matricaria chamomilla, her iki ekstraktın 500 ppm'lik dozu için sırasıyla yüksek ve orta ölüm oranı göstermiştir.

Sonuçlarımız, yüksek larvisidal aktiviteye, Salvia verticillata, Leucanthemum vulgare, Inula vulgaris ve Matricaria chamomilla 'nın etil asetat ve metil alkollü ham özütlerinden elde edilen ürünlerin sahip olduğunu göstermiştir. Ancak, sivrisinek kontrolüne karşı yeni ve daha güvenli kontrol ürünleri için olası aday türler hakkında daha fazla araştırma yapılması gerekir.. 


\section{INTRODUCTION}

Mosquitoes are responsible for transmitting several infectious diseases like malaria, yellow fewer, dengue, West nile encephalitis, filariasis, zika, chikungunya (Nauen, 2007; Kovendan et al., 2012; Govindarajan et al., 2013). For this reason, public health is becoming a challenging problem and mosquitoes and their transmitting diseases have a serious social and economic impact for many countries in tropical and subtropical areas (Bossche \& Coetzer, 2008). The distribution of mosquitoes is dynamic in space and time and their life cycles are influenced by environmental conditions (Crans, 2004). Climate change seems to be a driving force for establishing new invasion areas for invasive Aedes mosquitoes (Caminade et al., 2012, Campbell et al., 2015). Mosquito-borne diseases are endemic in more than 100 countries all over the world, and new ones are added every year (Ogden 2018). They are causing serious public health problems and mortality of two million people every year. More than two billion people are at risk around the world related to mosquito borne diseases (Klempner et al., 2007).

In Turkey, various genera of mosquitoes, such as Aedes, Anopheles, Culex are important for mosquito borne diseases. Recently Aedes albopictus and A. aegypti introduced and established populations in Eastern Blacksea part and raises concerns about a possible resurgence of the pathogens that can be transmitted by this vector species (Akıner et al., 2016). Increase of the human population and movement are raising the transmission risk of the pathogens especially yellow fewer, dengue, chikungunya, West Nile fewer and zika. Limited funds of mosquito control, lack of awareness among the residents and highly competent behaviour of the invasive vector species resulted in an increase in mosquito borne diseases (Gubler, 1998). Mosquito control efforts are the best strategy for protection against mosquito-borne diseases. Usage of the syntetic insecticides is the most important method for controlling mosquito and other pests for human and animal health. But, extensive usage of synthetic insecticides causes environmental problems and development resistance. Furhermore, it causes toxic and detrimental/lethal effects on non-target organisms (Roberts \& Andre, 1994; Milam et al., 2000; Dinesh et al. 2015, Sakthivadivel et al., 2015). Pyhtochemicals obtained from plants are mainly biodegradable, non-phytotoxicity and more importantly, they are renewable (Çalmaşur et al., 2006; Boulogne et al., 2012). In this respect, plant and plant derived substances regain interest to control of insect pests.

Plant secondary products as terpenoids, flavonoids and phenolic compounds which serve as storage compounds in plants are important for plant defence mechanisms against insects and used as an excellent alternative to synthetic or chemical insecticide in many parts of the World (Luthria et al., 1993; Ghosh et al 2012; Ali et al., 2015; Hikal et al., 2017). Especially, plants with high terpenoid, phenolic compound and alkaloid content are known to be used for this purpose. Therefore, the insecticidal, larvicidal, ovicidal, antifeedant and repellent activity of many plants belongs to Asteraceae and Lamiaceae families due to the rich terpenoid content in the crude extract or their components have been described in several studies (Çalmaşur et al., 2006; Pavela 2008, Boussaada et al., 2008;.Çetin et al., 2009; Govindarajan \& Karuppannan, 2011, Boulogne et al., 2012; Cheah et al., 2013).

Salvia vertisillate L., Phlomis lychitis L., Salvia tomentosa Mill., are belonging to the Lamiaceae family. Many species of the genera Salvia and Phlomis over the Mediterranean region native to Turkey, North Africa, Europe and Asia are used as herbal tea for many decades in folk medicine as sore throats, colds, gastrointestinal disorder among others (Orhan et al., 2007; Tepe et al., 2007; Amor et al., 2009; Lopez et al., 2010; Aşkun et al., 2010). The other five plants (Matricaria chamomilla L., Leucanthemum vulgare (vall.) Lam., Triploaraspermum caucasicum (Wild.) Haya, Erigeron annuus (L.) Pers, Inula vulgaris (Lam.) Trevisan) belonging to the Asteraceae family are also subject of chemical screening and bioactivity studies and used for folk medicine (Singh et al., 2011; Kumar et al., 2014; Magharri et al., 2015; Assi et al., 2017). There are a number of reports on the isolation of various secondary metabolites and phytochemical analysis from all of these plants, e.g., monoterpenoids, sesquiterpenoids, diterpenoids, alkaloids, flavonoids and other phenolics coumpounds (Sefidkon et al., 1999; Chalchat et al., 2001; Pitarokili et al., 2006; Amor et al., 2009; Nazaruk and Kalemba, 2009; Aşkun et al., 2010; Ayoughi et al., 2011; Singh et al., 2011; Kumar et al., 2014; Magharri et al., 2015; Hatipoğlu et al., 2016; Assi et al., 2017; Kim et al., 2018). Salvia verticillate L., Salvia tomentosa, Matricaria camomilla, Leucanthemum vulgare (vall.) Lam., Erigeron annuus (L.) Pers plant extracts have been determined by some researchers in recent years with phytochemical analyses by using classic or spectral methods. According to these studies, the major chemical compositions of Turkish S. verticillate L. and S. tomentosa plant extracts are monoterpenes such as $\beta$-pinene, $\alpha$-pinene, borneol, camphor and sesquiterpenes such as caryophyllene oxide, $\alpha$ / $\beta$-caryophyllene, $\gamma$-muurulone (Chalchat et al., 2001; Pitarokili et al., 2006; Aşkun et al., 2010). The essential oils of M. camomilla, L. vulgare (vall.) Lam. and E. annuus (L.) Pers extracts contain $\alpha$-bisabolol, $\alpha$ - / $\beta$-farnesene, guaiazulene, $\beta$-caryophyllene, caryophyllene oxide as major components (Ayoughi et al., 2011; Kumar et al., 2014; Magharri et al., 2015; Kim et al., 2018). These components are found in these plants but with different amounts. Differences among chemical compositions of the crude oils or essetial oils widely depend on conditions such as climate, variety, origin, time and soil factors.

Many Salvia species have been reported to have insecticidal activities. According to these records, methanolic ectract of Salvia vertisillate L. and hexane ectract of Salvia tomentosa Mill. have moderate larvacidal activity against Culex tritaeniorhynchus and Culex pipiens (Diptera: 
Culicidae), respectively (Pavela, 2008; Gün et al., 2011). Also, essential oils of Salvia tomentosa Mill. have insecticidal activity against Lipaphis pseudobrassicae (Aphididae: Homoptera), Spodoptera exigua (Lepidoptera) (Sampson et al., 2005; Polatoğlu et al., 2017). Khodadad et al. (2007) reported that acaricidal potential against female Rhipicephalus annulatus (Ixodidae) of Matricaria chamomile ethanolic extract. In another report, ethanolic extract of Matricaria chamomile has showed oviposition deterrent, larvacidal and repellent activity against Culex quinquefasciatus (Al-Mehmadi \& Al- Khalaf 2008; Gad \& El-DaKheel 2009). Literature survey has shown that there are no such studies for our other studied plants.

The present study aims to evaluate potential larvacidal activity of eight different plants (Lamiaceae and Asteracea), are grown naturally in Turkey against Aedes albopictus larvae.

\section{MATERIALS and METHODS}

Plant material: Fresh aerial parts of Salvia vertisillate L. and Salvia tomentosa Mill. were collected from Antalya in southwest part of Turkey in April 2018 and May 2018, respectively (Table 1). Dried aerial parts of Phlomis lychitis L. were purchased from a market in Konya, southwest part of Turkey in May 2018. Matricaria chamomilla L., Leucanthemum vulgare (vall.) Lam., Triploaraspermum caucasicum (Wild.) Haya, Erigeron annuus (L.) Pers, Inula vulgaris (Lam.) Trevisan, were collected from Rize in northeast part of Turkey in MayAugust 2018 (Table 1) and transported to the laboratory. The identification of the plants was performed by Prof. Vagif Atamov (Faculty of Science and Arts, Recep Tayyip Erdogan University in Rize, Turkey).
Plant Extracts: The solvents (n-hexane, $\mathrm{CHCl}_{3}$, $\mathrm{MeOH}, \mathrm{AcOEt}$ ) used were either of analytical grade or bulk solvents distilled before use. Electric blender was used as a Waring Commercial (CT, USA). Ultrasonic bath was Bandelin Sonorex (Berlin, Germany).

Fresh plant materials were cleaned and washed with distillated water and ethyl alcohol mixture $(1: 1, \mathrm{v} / \mathrm{v})$. Then, these materials were dried for one week at room temperature with reduced humidity $(25 \%)$ and whole plants were powdered using an electric blender. The resulting powder of each plant samples was divided into two flasks, $100 \mathrm{~g} /$ flask. Extraction procedure is the method developed by Selvi et al., (2018). Each sample was defatted with $100 \mathrm{~mL}$ of chloroform at $25{ }^{\circ} \mathrm{C}$ for 30 minutes. Two different solvent extractions of each sample were performed with 2 x $400 \mathrm{~mL}$ of solvent at room temperature for $2 \mathrm{~h}$ in a shaker. The most preferred solvent for phenolic coumpounds extraction is methanol, because the phenolic composition at plant samples is mostly soluble and stable in this solvent. Ethyl acetate is mostly suitable for flavonoid extraction (Dmitrienko et al. 2012; Mokrani and Madani 2016; Sukeksi and Sarah 2016). Therefore, plant extractions were performed using two different polarities: methanol and ethyl acetate. The crude extracts were filtrated and dried under vacuum in a rotary evaporator at $40^{\circ} \mathrm{C}$ and then lyophilized. A stock solution of each crude extract was prepared in DMSO and stored below $4{ }^{\circ} \mathrm{C}$ until testing for bioassay. Crude oil yields obtained from extractions with different solvents of studied plant have been given in Table 1. In this study, larvacidal activities of 50 and $500 \mathrm{ppm}$ doses of crude extracts obtained from eight plants against Ae albopictus (Diptera: Culicidae) have been tested.

Table 1. Plants used in this study, their parts used, origins and crude oil yields.

\begin{tabular}{|c|c|c|c|c|c|c|}
\hline \multirow{2}{*}{ Plant species } & \multirow{2}{*}{ Plant family } & \multirow{2}{*}{ Common name } & \multirow{2}{*}{ Plant part } & \multirow{2}{*}{ Origin and date } & \multicolumn{2}{|c|}{ Crude oil yield (\%) } \\
\hline & & & & & МеОН & EtOAc \\
\hline Salvia vertisillate $\mathrm{L}$. & Lamiaceae & lilac sage & aerial part & Antalya, April 2018 & 2.58 & 1.72 \\
\hline Phlomis lychitis L. & Lamiaceae & lampwick plant & aerial part & Konya, May 2018 & 3.77 & 2.46 \\
\hline Salvia tomentosa Mill. & Lamiaceae & balsamic sage & aerial part & Antalya,May 2018 & 2.07 & 4.73 \\
\hline Matricaria chamomilla L., & Asteraceae & chamomile & aerial part & Rize, May 2018 & 2.62 & 1.97 \\
\hline Leucanthemum vulgare (vall.) Lam. & Asteraceae & ox-eye daisy & aerial part & Rize, July 2018 & 2.94 & 2.47 \\
\hline Triploaraspermum caucasicum (Wild.) Haya & Asteraceae & vulture weed & aerial part & Rize, July 2018 & 4.62 & 4.03 \\
\hline Erigeron annuus (L.) Pers & Asteraceae & fleabane & aerial part & Rize, August 2018 & 4.55 & 2.47 \\
\hline Inula vulgaris (Lam.) Trevisan & Asteraceae & ploughman's spikenard & aerial part & Rize, August 2018 & 2.78 & 3.33 \\
\hline
\end{tabular}

Test organisms: Aedes albopictus was collected from Rize province in July 2018 in around whole sales market (41,0416 Lat 40,5771 Lan) / small industirial area (41,0453 Lat 40,5784 Lan) and used for the larvicidal activity. Whole samples collected larval stages in inside used tires. Alive collected larvae transferred to the laboratory and colonised in the laboratory condition. Mosquitoes were held at $26 \pm 2{ }^{\circ} \mathrm{C}, 65 \pm 10 \%$ relative humidity and a photoperiod regime of 14:10 $\mathrm{h}(\mathrm{L}: \mathrm{D})$ in the insectarium. The larvae were fed on larval food. Adult mosquitoes were periodically fed with $10 \%$ glucose solution (Gerbert et al., 1994, Imam et al., 2014). F1 and F2 generation larvae were used for tests.

Larvicidal bioassay: The larvacidal activity against Ae albopictus was analysed with minor modifications adopted for the study in standard protocol recommended by the World Health Organization (WHO) (WHO, 2005). The 
tests were conducted in $250 \mathrm{~mL}$ plastic container. Tested third or early fourth instar mosquito larvae were obtained from laboratory colonized mosquitoes of $\mathrm{F} 1$ and F2 generation. From the stock solution, different concentrations 50 and $500 \mathrm{ppm}$ with distillated water were prepared. Twenty healthy larvae were released into each $250 \mathrm{~mL}$ plastic container containing $200 \mathrm{~mL}$ of water and two hours after test extracts (50-500 ppm) were added the plastic container. Controls made with DMSO solution were performed simultaneously. Larval mortality was observed for 24 and 48 hours. The larval percent mortality was calculated. All tests were done in two replications and control mortality was corrected using Abbott's formula (Abbott, 1925).

\section{RESULTS AND DISCUSSION}

The results of larvacidal affects of S. verticillate L., S. tomentosa (Mill.) extracts showed low level effects on Ae albopictus except $S$. verticillate $\mathrm{L}$. methanol and ethyl acetate extracts $500 \mathrm{ppm}$ dose. S. verticillate L. bioassay results showed high larval mortality (up to $85 \%$ for $500 \mathrm{ppm}$ dose) but $S$. tomentosa extracts showed low larval mortality (under $15 \%$ for 50 and 500 ppm doses). Similarly, P. lychitis L. extracts showed low level mortality for two doses (under 20 \%) (Table 2). Gün et al. (2011) showed larvicidal effects of some Salvia species hexane extracts on Culex pipiens larvae. They used four different Salvia species (S. tomentosa, S. scleerae, S. argentea, S. syriaca) and tested against $C X$ pipiens $3^{\text {th }}$ and $4^{\text {th }}$ instar larvae. They indicated that $S$. tomentosa is the most effective Salvia species against $C x$ pipiens larvae. In contrast to these results, S. vertisillate species showed higher larvicidal effect against Ae albopictus larvae and gived high mortality rate after 24 and $48 \mathrm{~h}$ in our study. S. tomatosa mortality rates were very low and also found $15 \%$ after $48 \mathrm{~h}$. Çetin et al. (2006) tested larvicidal activities some Lamiaceae species against $C x$ pipiens larvae. In that study, ethanol etxract of the Salvia sclerae showed high larvicidal activity and $200 \mathrm{ppm}$ ethanol extract gived 90 $\%$ mortality after $24 \mathrm{~h}$. Kaliopoulos et al. (2010) reported the larvacidal activity of Salvia fruticosa Mill., Salvia pomifera L. subsp. calycina (Sm.) Hayek and Salvia pomifera L. subsp. pomifera essential oils against Cx pipiens larvae. All these studies have shown different/similar larvicidal activity of many Salvia species related to the polar/apolar solvent extracts and mosquito species.

Different daisy extracts results showed moderate and high mortaliy especially in methanol and ethyl acetate high dose experiments. M. camomilla bioassay revealed that the low level mortality of methanol extracts low dose for two test duration. But, the high dose of this extract gived $75 \%$ mortality for $48 \mathrm{~h}$ duration. Ethyl acetate extracts bioassay results showed moderate (ethyl acetate $50 \mathrm{ppm} 48 \mathrm{~h}$ ) and high mortality for two test duration. A similar study of Gad \& El-DaKheel (2009) showed that the larvicidal activity of M. chamomilla against $C x$ quinquefastiatus larvae and determined $0.310 \mathrm{mg} / \mathrm{L} \mathrm{LC}_{50}$ value for $4^{\text {th }}$ instar larvae. $\mathrm{Al}-$ Mehmadi (2011) also reported that the larvacidal activity of $M$. chamomilla extracts against $C x$ quinquefasciatus and indicated that the duration is important for the $\mathrm{LC}_{50}$. They showed $0.505 \mathrm{mg} / \mathrm{L}$ after $28 \mathrm{~h} \mathrm{LC}_{50}$ value and $0.301 \mathrm{mg} / \mathrm{L}$ after $48 \mathrm{~h}$ from treatment. Another study of Al-Mehmadi \& Al- Khalaf (2008) reported that ethanolic extracts of $M$. chamomilla had oviposition deterrent and skin repellent against Cx quinquefasciatus. Mahyoub et al. (2014) reported that larvicidal effects of $M$. chamomilla extract against $A e$ aegypti larvae. They indicated that the concentration is important for the incrasing larval mortality against $4^{\text {th }}$ instar Ae aegypti larvae. Candido et al. (2013) reported that the high larval and pupal mortality with $R$. communis and $C$. phyllacanthus oils against Ae aegypti larvae. They also indicated that the lethality was enhanced with increasing time of exposure to plant products. Our results also indicated that mortality increasing with time.

L. vulgare (vall.) Lam. extracts also showed similar results as M. chamomilla, but methanol $500 \mathrm{ppm}$ and ethyl acetate $50 \mathrm{ppm}$ results showed moderate mortality for two test duration. The highest mortality result for this plant was seen at $500 \mathrm{ppm}$ of ethyl acetate extract $(100 \%, 24 \mathrm{~h}$ and 48 h).

T. caucasicum (Wild.) Haya extracts showed low level mortality for whole extracts and duration except ethyl acetate $500 \mathrm{ppm} 48 \mathrm{~h}$ duration ( $75 \%$ mortality). Almost similar results were found in E. annuus (L.) Pers and ethyl acetate $500 \mathrm{ppm} 48 \mathrm{~h}$ duration showed $67.5 \%$ mortality.

I. vulgaris (Lam.) Trevisan methanol and ethyl acetate low doses showed low level mortality for two test duration. In contrast to these results, high doses of methanol extract gived moderate mortality for two test duration and high doses of ethyl acetate extracts gived high mortality for two test duration. In a similar study, $\mathrm{He}$ et al. (2014) described larvicidal activity of another Inula species (I. racemosa) root ethanol extract against Ae albopictus larvae. They showed that $25.23 \mu \mathrm{g} / \mathrm{mL} \mathrm{LC}_{50}$ value of ethanol extract.

There are numerous studies on plant extracts against mosquito larvae. Insects and especially mosquitoes control becomes more diffucult day by day related to the insecticide resistance. Literature survey has shown that there is no report on larvicidal activity of $P$. lychitis, $L$. vulgare, $T$. caucasicum, E. annuus unlike other tested species. Botanical orginated insecticides may have a chance for safe control option beyond the harmfull effects of synthetic insecticides and also may help to solve insecticide resistance obstacle for mosquito control. This study indicates that the methanol and ethyl acetate extract of Salvia and some daisy species naturally found in our country have a potential to be used for the control of Ae albopictus. Therefore, more detailed studies are needed for exact and effective candidate of invasive Aedes species recently distrubited in Turkey. 
Table 2. Mortality rate of Aedes albopictus by different concentrations of some plant extracts belonging to Asteraceae and Lamiaceae families.

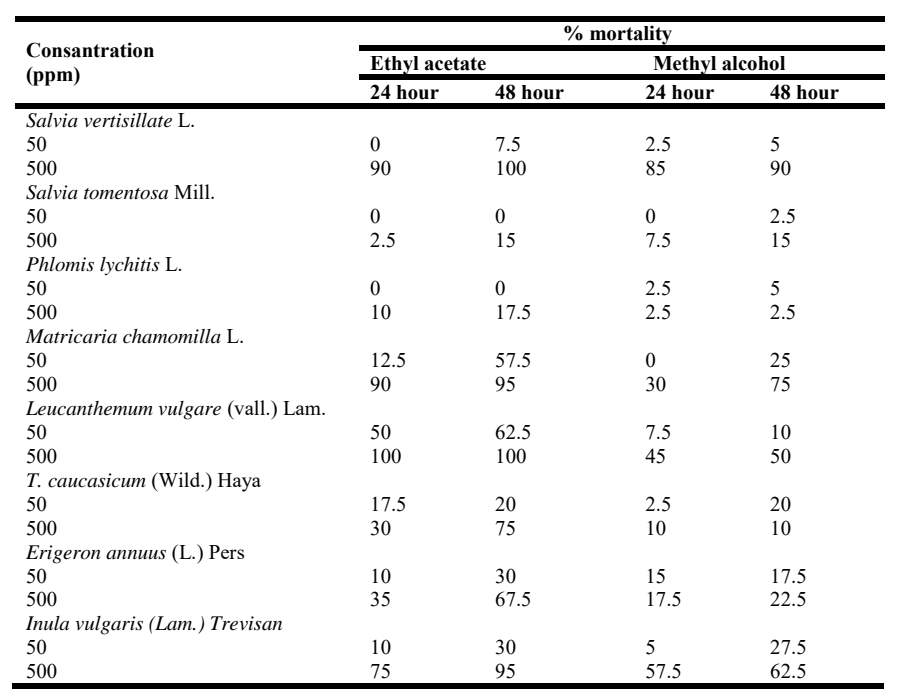

\section{REFERENCES}

Abbott, W.S. (1925). A method of computing the effectiveness of an insecticide. Journal of Economic Entomology, 18, 265-267.

Akiner, M.M., Demirci, B., Babuadze, G., Robert, V. \& Schaffner F. (2016). Spread of the invasive mosquitoes Aedes aegypti and Aedes albopictus in the Black Sea Region increases risk of chikungunya, dengue, and zika outbreaks in Europe. PLOS Neglected Tropical Diseases, 10, e0004664.

Ali, A., Tabanca, N., Demirci, B., Blythe, E.K., Ali, Z., Baser, K.H.C. \& Khan, I.A. (2015). Chemical composition and biological activity of four Salvia essential oils and individual compounds against two species of mosquitoes. Journal of Agriculture and Food Chemistry, 63, 447-456.

Al-Mehmadi, R.M \& Al- Khalaf. A. A. (2008). Oviposition deterrent and skin repellent activites of Artemisa herba alba, Matricharia chamomella and Mellia azedarach against C. quinquefasciatus. Saudi.Journal of Biological Sciences, 15, 97-104.

Al-Mehmadi, R.M. (2011). Larvicidal, histopathological and ultra - structure studies of Matricharia chamomell extract rift valley fever mosquito Culex quinquefasciatus (Diptera: Culicidae). Journal of Entomology, 8, 63-72.

Amor, I.L., Boubaker, J., Sgaier, M.B., Bhouri, I.S.W, Neffati, A., Kilani, S., Bouhlel, I., Ghedira, K. \& Chekir-Ghedira, L. (2009). Phytochemistry and biological activities of Phlomis species, Journal of Ethnopharmacology, 125, 183-202.

Assı, M., Usta, J., Mounımne, Y., Aboul-Ela, M. \& ElLakany, A. (2017). Phytochemical study and the antiproliferative activity of Inula vulgarıs species grown in lebanon. International Journal of Pharmacy and Pharmaceutical Sciences, 9, 75-83.

Aşkun, T., Başer, K.H.C., Tümen, G. \& Kürkçüoğlu, M. (2010). Characterization of essential oils of some Salvia species and their antimycobacterial activities. Turkish Journal of Biology, 34, 89-95.

Ayoughi, F., Barzegar, M., Sahari, M.A. \& Naghdibadi, H. (2011). Chemical compositions of essential oils of Artemisia dracunculus L. and endemic Matricaria chamomilla L. and an evaluation of their antioxidative effects. Journal of Agriculture Science and Technology, 13, 79-88.

Bossche, V. \& Coetzer, J.A. (2008). Climate change and animal health in Africa. Revue scientifique et technique, 27, 551-562.

Boulogne, I., Petit, P., Ozier-Lafontaine, H., Desfontaines, L. \& Loranger-Merciris, G. (2012). Insecticidal and antifungal chemicals produced by plants: a review. Environmental Chemistry Letter, 10, 325347.

Boussaada, O., Kamel, M.B.H., Ammar, S., Haouas, D., Mighrı, Z. \& Helal, A.N. (2008). Insecticidal activity of some Asteraceae plant extracts against. Tribolium confusum. Bulletin of Insectology, 61, 283-289.

Caminade, C., Medlock, J.M., Ducheyne, E., McIntyre, K.M., Leach, S., Baylis, M. \& Morse, A.P. (2012). Suitability of European climate for the Asian tiger mosquito Aedes albopictus: recent trends and future scenarios. J. R. Soc. Interface 9, 2708-2717.

Campbell, L.P., Luther, C., Moo-Llanes, D., Ramsey, J.M., Danis-Lozano, R. \& Peterson, AT. (2015) Climate change influences on global distributions of dengue and chikungunya virus vectors. Phil. Trans. R. Soc. B, 370, 20140135.

Candido, L.P., Cavaltini M.J., Beserra E.B. (2013). Bioactivity of plant extracts on the larval and pupal stages of Aedes aegypti (Diptera, Culicidea). Revista da Sociedade Brasileira de Medicina Tropical 46(4):420-425.

Chalchat, J.C., Gorunovic, M.S., Petrovic, S.D. \& Maksimovic, Z.A., (2001). Chemical Compositions of Two Wild Species of the Genus Salvia L. from Yugoslavia: Salvia aefhiopis and Salvia verficillafa. Essential Oil Research, 13, 416-418.

Cheah, S.X., Tay, J.W., Chan, L.K. \& Jaal, Z. (2013). Larvicidal, oviposition, and ovicidal effects of Artemisia annua (Asterales: Asteraceae) against Aedes aegypti, Anopheles sinensis, and Culex quinquefasciatus (Diptera: Culicidae). Parasitology Research, 112, 3275-3282. 
Crans, W.J. (2004). A classification system for mosquito life cycles: life cycle types for mosquitoes of the northeastern United States. Journal of Vector Ecology, 1, 1-10.

Çalmaşur, Ö., Aslan, İ. \& Şahin., F. (2006). Insecticidal and acaricidal effect of three Lamiaceae plant essential oils against Tetranychus urticae Koch and Bemisia tabaci Genn. Industrial Crops and Products, 23, 140-146.

Çetin, H., Cinbilgel, I., Yanikoglu, A. \& Gokceoglu, M. (2006) Larvicidal Activity of some Labiatae (Lamiaceae) Plant Extracts from Turkey. Phytotherapy Research, 20, 1088-1090.

Çetin, H., Çilek, J.E., Aydın, L. \& Yanıkoğlu, A. (2009). Acaricidal effects of the essential oil of Origanum minutiflorum (Lamiaceae) against Rhipicephalus turanicus (Acari: Ixodidae). Veterinary Parasitology, 160, 359-361.

Dinesh, D.S., Kumari, S., Pandit, V., Kumar, J., Kumari, N., Kumar, P., Hassan, F., Kumar, V. \& Das, P. (2015). Insecticidal effect of plant extracts on Phlebotomus argentipes (Diptera: Psychodidae) in Bihar, India. Indian Journal of Medicinal Research, 142, 95-100.

Dmitrienko, S.G., Kudrinskaya, V.A. \& Apyari, V.V. (2012). Methods of extraction, preconcentration, and determination of quercetin. Journal of Analytical Chemistry 67, 299-311.

Gad, A.A. \& El-DaKheel, A.A. (2009). Larvicidal activities of Cinnamomum osmophloeum and Matricharia chamomella extracts against the filarial mosquito Culex quinquefasciatus (Diptera:Culicidae) and their effects on its haemogram. The Egyptian Science Magazine, 6(1/2), 8-15.

Gerberg, E.J., Barnard, D.R. \& Ward, R.A. (1994). Manual for mosquito rearing and experimental techniques. American Mosquito Control Association.

Ghosh, A., Chowdhury, N. \& Chandra, G. (2012). Plant extracts as potential larvicides. Indian Journal of Medical Research, 135, 581-598.

Govindarajan, M., Sivakumar, R., Rajeswary, M. \& Yogalakshmi, K. (2013). Chemical composition and larvicidal activity of essential oil from Ocimum basilicum (L.) against Culex tritaeniorhynchus, Aedes albopictus and Anopheles subpictus (Diptera: Culicidae). Experimental Parasitology, 134, 7-11.

Gubler, D.J. (1998). Resurgent vector-borne diseases as a global health problem. Emerging Infectious Diseases, 4, 1-9.

Gün, S.Ş., Çinbilgel, I., Öz, E. \& Çetin H. (2011). Larvcidal acitivity of some Salvia L. (Labiatae) plant extracts against the mosquito Culex pipiens
L. (Diptera: Culicidae). Kafkas Üniversitesi Veteriner Fakültesi Dergisi, 17(Suppl A), 61-65.

Hatipoğlu, S.D., Zorlu, N., Dirmenci, T., Gören, A.C., Özturk, T. \& Topçu, G. (2016). Determination of volatile organic compounds in fourty five Salvia Species by thermal desorption-GC-MS technique. Records of Natural Products, 10, 659-700.

He, Q., Liu, X.C., Sun, R.Q., Deng, Z.W., Du, S.S. \& Liu, Z.L. (2014). Mosquito Larvicidal Constituents from the Ethanol Extract of Inula racemosa Hook. f. Roots against Aedes albopictus. Journal of Chemistry, 2014(Article ID 738796), 1-6.

Hikal, W.M., Baeshen, R.S. \& Said-Al Ahl, H.A.H. (2017). Botanical insecticide as simple extractives for pest control. Cogent Biology, 3, 1404274.

Imam, H., Zarnigar, S.G. \& Seikh, A. (2014). The basic rules and methods of mosquito rearing (Aedes aegypti). Trop Parasitol, 4(1), 53-55.

Khodadad, P.K. \& Mehdi, R.A. (2007). Biological activities of chamomile (Matricaria chamomile) flowers' extract against the survival and egg laying of the cattle fever tick (Acari Ixodidae). Journal of Zhejiang University: Science B, 8, 693-696.

Kim, D.Y., Won, K.J., Hwang, D.I., Park, S.M., Kim, H.B. \& Lee, H.M. (2018). Chemical Composition of Essential Oil from Erigeron annuus (L.) Pers. Flower and its Effect on Migration and Proliferation in Keratinocyte. Journal of Essential Oil Bearing Plants, 21, 1146-1154.

Klempner, M.S., Unnasch, T.R. \& Hu, L.T. (2007). Taking a bite out of vector-transmitted infectious diseases. The New England Journal of Medicine, 356, 25672569.

Koliopoulos, G., Pitarokili, D., Kioulos, E., Michaelakis, A. \& Tzakou, O. (2010). Chemical composition and larvicidal evaluation of Mentha, Salvia, and Melissa essential oils against the West Nile virus mosquito Culex pipiens. Parasitology Research, 107, 327-335.

Kovendan, K., Murugan, K., Kumar, A.N., Vincent, S. \& Hwang, J.S. (2012). Bioefficacy of larvicdial and pupicidal properties of Carica papaya (Caricaceae) leaf extract and bacterial insecticide, spinosad, against chikungunya vector, Aedes aegypti (Diptera: Culicidae). Parasitology Research, 110, 669-678.

Kumar, V., Mathela, C.S., Tewari, G., Singh, D., Tewari, A.K. \& Bisht, K.S. (2014). Chemical composition and antifungal activity of essential oils from three Himalayan Erigeron species. LWT-Food Science and Technology, 56, 278-283.

López, V., Jäger, A.K., Akerreta, S., Cavero, R.Y. \& Calvo, M.I. (2010). Antioxidant Activity and Phenylpropanoids of Phlomis lychnitis L.: A 
Traditional Herbal Tea. Plant Foods for Human Nutrition, 65, 179-185.

Luthria, D.L., Ramakrishnan, V. \& Banerji, A. (1993). Insect antifeedant activity of furochromones: Structure-activity relationships. Journal of Natural Products, 56, 671-675.

Magharri, E., Razavi, S.M., Ghorbani, E., Nahar, L. \& Sarker, S.D. (2015). Chemical composition, some allelopathic aspects, free-radical-scavenging property and antifungal activity of the volatile oil of the flowering tops of Leucanthemum vulgare Lam. Records of Natural Products, 9, 538-545.

Milam, C.D., Farris, J.L. \& Wilhide, J.D. (2000). Evaluating mosquito control pesticides for effect on target and nontarget organisms. Archives of Environmental Contamination and Toxicology, 39, 324-328.

Mokrani, A. \& Madani, K. (2016). Effect of solvent, time and temperature on the extraction of phenolic compounds and antioxidant capacity of peach (Prunus persica L.) fruit. Separation and Purification Technology, 162, 68-76.

Nauen, R. (2007). Insecticide resistance in disease vectors of public health importance. Pest Management Science, 63, 628-633.

Nazaruk, J. \& Kalemba, D. (2009). Chemical composition of the essential oils from the roots of Erigeron acris L. and Erigeron annuus (L.) Pers. Molecules, 14, 2458-2465.

Ogden, L. E. (2018). Climate change, pathogens, and people. BioScience, $68(10), 733-739$.

Orhan, I., Kartal, M., Naz, Q., Ejaz, A., Yilmaz, G., Kan, Y., Konuklugil, B., Sener, B. \& Choudhary, M.I. (2007). Antioxidant and anticholinesterase evaluation of selected Turkish Salvia species. Food Chemistry, 103, 1247-1254.

Pavela, R. (2008). Larvicidal effects of various Euro-Asiatic plants against Culex quinquefasciatus Say larvae (Diptera: Culicidae), Parasitology Research, 102, 555-559.

Pitarokili, D., Tzakou, O. \&. Loukis, A. (2006). Essential oil composition of Salvia verticillata, $S$. verbenaca, S. glutinosa and S. Candidissima growing wild in Greece. Flavour and Fragrange Journal, 21, 670-673.

Polatoğlu, K., Karakoç, E.C., Yücel, Y.Y., Gücel, S., Demirci, B., Demirci, F. \& Başer, K.H.C. (2017). Insecticidal activity of Salvia veneris Hedge. Essential oil against coleopteran stored product insects and Spodoptera exigua(Lepidoptera). Industrial Crops and Products, 97, 93-100.

Roberts, D.R. \& Andre, R.G. (1994). Insecticide resistance issues in vector borne disease control. The
American Journal of Tropical Medicine and Hygiene, 50, 21-34.

Sakthivadivel, M., Gunasekaran, P., Sivakumar, M., Arivoli, S., Raveen, R. \& Tennyson, S. (2015). Mosquito larvicidal activity of Hyptis suaveolens (L.) Poit (Lamiaceae) aerial extracts against the filarial vector Culex quinquefasciatus Say (Diptera: Culicidae). Journal of Medicinal Plants Studies, 3, 1-5.

Sampson, B.J., Tabanca, N., Kirimer, N., Demirci, B., Baser, K.H.C., Khan, I.A., Spiers, J.M. \& Wedge, D.E. (2005). Insecticidal activity of 23 essential oils and their major compounds against adult Lipaphis pseudobrassicae (Davis) (Aphididae: Homoptera). Pest Management Science, 61, 1122-1128.

Sefidkon, F. \& Khajavi, M.S. (1999). Chemical composition of the essential oils of two Salvia species from Iran: Salvia verticillata L. and Salvia santolinifolia Boiss. Flavour Fragrange Journal, 14, 77-78.

Selvi, E.K., Turumtay, H., Demir, A. \& Turumtay, E.A. (2018). Phytochemical profiling and evaluation of the hepatoprotective effect of Cuscuta campestris by high-performance liquid chromatography with diode array detection. Analytical Letters, 51, 3-15.

Singh, O., Khanam, Z., Misra, N. \& Srivastava, M. (2011). Chamomile (Matricaria chamomilla L.): An overview. Pharmacognosy Review, 5, 82-95.

Sukeksi, L. \& Sarah, M. (2016). Characterizations and extraction of polyphenols from residual pulp of pink guava as source of antioxidants. Journal of Engineering and Applied Sciences, 11, 5209-5216.

Tepe, B., Eminağaogğlu, O., Akpulat, H.A. \& Aydin, E. (2007). Antioxidant potentials and rosmarinic acid levels of the methanolic extracts of Salvia verticillata (L.) subsp. verticillata and $S$. verticillata (L.) subsp. amasiaca (Freyn \& Bornm.) Bornm. Food Chemistry, 100, 985-989.

WHO. (2005). Guidelines for laboratory and field testing of mosquito larvicides, WHO/CDS/WHOPES/GCDPP/2005.13, Geneva, Switzerland.
*Corresponding author's:
Emine KILIÇKAYA SELVİ
Department of Chemistry, Faculty of Arts and Sciences, Recep Tayyip Erdogan University, 53100 Rize, TURKEY
E-mail: emine.selvi@erdogan.edu.tr
ORCID: https://orcid.org/0000-0003-0291-5362 